\title{
Solar water heating in residential building
}

\author{
Pathomthat Chiradeja ${ }^{a}$ Chaichan Pothisarn ${ }^{\mathrm{b}}$, Chaiyan Jettanasen ${ }^{\mathrm{b}}$, Suntiti \\ Yoomak ${ }^{\mathrm{b}}$, Panapong Songsukthawan ${ }^{\mathrm{b}}$, Sulee Bunjongjit ${ }^{\mathrm{c}}$, Monthon \\ Leelajindakrairerk $^{\mathrm{b}}$, Atthapol Ngaopitakkul ${ }^{\mathrm{b}}{ }^{\mathrm{c}}$ \\ ${ }^{a}$ Faculty of Engineering, Srinakharinwirot University, Bangkok, Thailand \\ ${ }^{b}$ Faculty of Engineering, King Mongkut's Institute of Technology Ladkrabang, Bangkok, Thailand \\ ${ }^{c}$ Faculty of Engineering, Rajamangala University of Technology Rattanakosin, Nakhon Pathom, Thailand
}

\begin{abstract}
The electrical consumption has been rapidly increased in the past few decades. However, environment concern and depleting of fossil fuel lead to raise of alternative energy. One of the applications for solar energy that has gain significant attention is solar thermal for watering heating that can replace electricity. This paper aims to presents feasibility on solar water heating for residential building in Thailand. The analysis has been done on both energy performance and economic perspective using RETscreen software and Bangkok, Thailand as case study location in order to verify the feasibility of solar water heating application in residential building. The result has shown the potential of solar water heating system application in residential building as a replacement to conventional electrical water heating.
\end{abstract}

Keywords: Solar water heating, economic analysis, residential building, renewable energy

\section{Introduction}

In the past few decades energy issue especially, electricity has become main concern for various countries around the globe. The demand of electrical energy has been constantly rising due to rapidly increase in population and economic growth. This issue also causes concern in Thailand with steadily growth in electricity energy demand. Thailand energy consumption in the first 6-month of 2017 and 2018 according to statistic data by Ministry of Energy is shown in Table 1 [1]. it can be seen that energy consumption in residential sector third largest at $37,300 \mathrm{GWh}$ or $24 \%$ share of total energy consumption following industrial and business sector respectively. Electricity demand is increasing by $39 \mathrm{GWh}$ or $0.2 \%$ compare to previous year.

Table 1. Hot water usage profile in residential building

\begin{tabular}{ccccccccc}
\hline Year & $\begin{array}{c}\text { Residential } \\
(\mathrm{GWh})\end{array}$ & $\begin{array}{c}\text { Business } \\
(\mathrm{GWh})\end{array}$ & $\begin{array}{c}\text { Industrial } \\
(\mathrm{GWh})\end{array}$ & $\begin{array}{c}\text { Government and } \\
\text { Non-Profit } \\
(\mathrm{GWh})\end{array}$ & $\begin{array}{c}\text { Agriculture } \\
(\mathrm{GWh})\end{array}$ & $\begin{array}{c}\text { Other } \\
(\mathrm{GWh})\end{array}$ & $\begin{array}{c}\text { Free of Charge } \\
(\mathrm{GWh})\end{array}$ & $\begin{array}{c}\text { Grand Total } \\
(\mathrm{GWh})\end{array}$ \\
\hline $\begin{array}{c}2017 \\
2018\end{array}$ & 22,189 & 25,128 & 36,989 & 102 & 218 & 1,753 & 1,543 & 91,173 \\
$\begin{array}{c}\text { Share } \\
(\%)\end{array}$ & 24.0 & 25.0 & 47.0 & 0.1 & 211 & 1,691 & 1,605 & 91,870 \\
$\begin{array}{c}\text { Growth } \\
\text { Rate } \\
(\%)\end{array}$ & 0.2 & 2.2 & 0.4 & 0.8 & -3.1 & -5.7 & 4.0 & 100.00 \\
\hline
\end{tabular}

This trend resulted in government extensive investment into expansion of power generation and transmission system to keep up with the demand. However, social and environmental concern from power

\footnotetext{
* Manuscript received September 21, 2018; revised May 30, 2019

Corresponding author. E-mail address: atthapol.ng@kmitl.ac.th.

doi: $10.12720 /$ sgce.8.4.422-429
} 
generation using burning fossil fuels has drastically effect that shift energy production toward much cleaner energy such as solar, wind, geothermal, biomass and biogas etc. One of a renewable energy application is using solar thermal to generated heat for water heating purpose instead of conventional electric water heating that require energy from electricity.

In case of Thailand, solar thermal application especially in solar water heating is still limited to large scale facility such as hotel, hospital or industrial building etc. due to residential building has small scale of water usage, limited area of system installation and cost of investment with residential building. So, the government by Energy Policy and Planning Office (EPPO), Ministry of Energy has proposed subsidy plan in order to promote application of solar water heating in residential building according to Alternative Energy Development Plan (AEDP2015) [2] that set the target for increase renewable energy proportion by $25 \%$ in 2030 . This also including plan to install solar water heating system at approximately 9.17 million square meters or 1,160 ktoe of heat equivalent. So, the analysis in term of both energy performance and economic feasibility must be done in order to evaluate the suitability of solar water heating application in Thailand residential building and possibility to achieve the government target plan.

Researches and studies on solar thermal system and its application has reviewed in this paper. The development of currently used solar heating and cooling system and will be develop in the future has been reviewed on Ge and et al research [3]. In [4], the current technologies of solar water heater and future work has been reviewed. The application of solar water heater in building was discussed in S. Krauter research [5]. In R. Bornatico and et al. research, the optimization of solar water heater using Particle Swarm Optimization (PSO) has been proposed [6]. The performance of solar water heating system in case with PCM and without has been analyzed [7] The Life Cycle Assessment (LCA) of solar water heater and behavior of the system operate under different condition has been discussed in Chr. Lamnatou and et al. works [8]-[10]. The study from Carnegie Mellon University presented the heating and cooling system using solar thermal on university ground with various factor that can impact system performance taken into consideration [11]. P. Dupeyut and et al. research proposed solar water heating performance evaluation using various climate factor that heavily influence on the system [12]. The simulation and software of solar water heating on residential building has been presented. The study has that taken various factor such as collector surface, tilt, shading etc. which has significant impact on solar water heating performance [13].

Case studies of solar water heating application from various countries that has been review in order to improvised to Thailand situation has also been done in this study. In China, the application of solar water heating systems installed in high-rise residential buildings has been proposed with key feature of the system being discussed [14]. CIESOL building in Spain has implement Heating, ventilation, and air conditioning (HVAC) integrate with solar power with satisfy result in both energy performance and reduction of energy cost [15]. In [16], the case study on solar water heating that installed on thermal insulation system of the building in order to used waste thermal that storage on insulation material to generated heat has been proposed.

From the researches and studies in various case studies, it can be seen that solar thermal application in field of solar water heating has a potential application in residential building by replace conventional electrical water heating to solar water heating in order to improve energy efficiency and reduce energy cost in building. This paper aims to presented feasibility analysis on application of solar thermal in solar water heating by using RETscreen software to validate system suitability in Thailand climate in term of both energy performance and economic perspective. The methodology and result from research can be used evaluate feasibility in various project to and attract new investment into installing solar water heating in residential building.

\section{Simulation}

The evaluation of solar water heating system has been done by using RETscreen software to analyze energy performance and economic perspective of proposed solar water heating system installed in residential building. The hot water usage profile in residential building using in case study is shown in 
Table 2. Residential building using in simulation consist of three occupancies with daily water usage at 180 liters per day. The supply hot water has inlet temperature approximately 27-28.5 degrees and outlet hot water that ready for usage is 55 degrees.

Table 2. Hot water usage profile in residential building

\begin{tabular}{ll}
\hline & Hot water load profile \\
\hline Occupancy rate & $100 \%$ \\
Daily hot water usage & $180 \mathrm{~L} / \mathrm{d}$ \\
Supply water temperature & $27-28.5^{\circ} \mathrm{C}$ \\
Hot water temperature & $55^{\circ} \mathrm{C}$ \\
Operating Hour & $24 \mathrm{hrs}$ \\
\hline
\end{tabular}

The simplified diagram of solar water heating using in case study residential building can be described in Fig. 1(a) and the diagram in RETscreen software is shown in Fig. 1(b). The system consists of solar collectors, hot water circulation pump and hot water storage tank. The process for water heating is supplying water to solar collector and receive thermal energy from the sun to heat water. After that the outlet hot water from collector will be storage in water tank before supply into residential building when there is demand. The detail of solar water heating system using in case study is shown in Table 3 . The system is installed on rooftop of residential building facing south direction. It consists of 3 units of glazed types solar collector with 150 liter of hot water storage capacity. The installation cost of the system is described in Table 4.

Table 3. Detail of solar water heating system using in research

\begin{tabular}{ll}
\hline & Specification \\
\hline Slope angle & 15 \\
Azimuth angle & 0 \\
Collector Type & Glazed \\
Gross area per solar collector & $2.2 \mathrm{~m} 2$ \\
Number of Collector & 3 \\
Solar collector area & $6.6 \mathrm{~m} 2$ \\
Capacity & $4.6 \mathrm{~kW}$ \\
Storage & Yes \\
Storage Capacity & $150 \mathrm{~L}$ \\
Heat exchange efficiency & $85 \%$ \\
Pump power & $8 \mathrm{~W} / \mathrm{m} 2$ \\
\hline
\end{tabular}

Table 4. Solar water heating installation cost

\begin{tabular}{lc}
\hline & Installation Cost a \\
\hline Initial Cost & 6,053 USD \\
O\&M Cost (annual) & 45 USD \\
Project Life & $20 \mathrm{yrs}$ \\
\hline
\end{tabular}

a exchange rate is $1 \mathrm{USD}=32.75 \mathrm{THB}$

The weather data in Bangkok area using for simulation consist of Temperature, Relative Humidity, Precipitation, Solar irradiance and Wind speed, which has significant impact on energy performance of the proposed system. The average value in each month throughout the year are shown in Table 5 and the relation between temperature and solar irradiance can be plot into graph as shown in Fig. 2. From the climate data on study area, it can be seen that temperature and solar irradiance are suitable for solar water heating throughout the years with high temperature and solar radiance due to Bangkok, Thailand is located near equator with tropical climate throughout the year. 


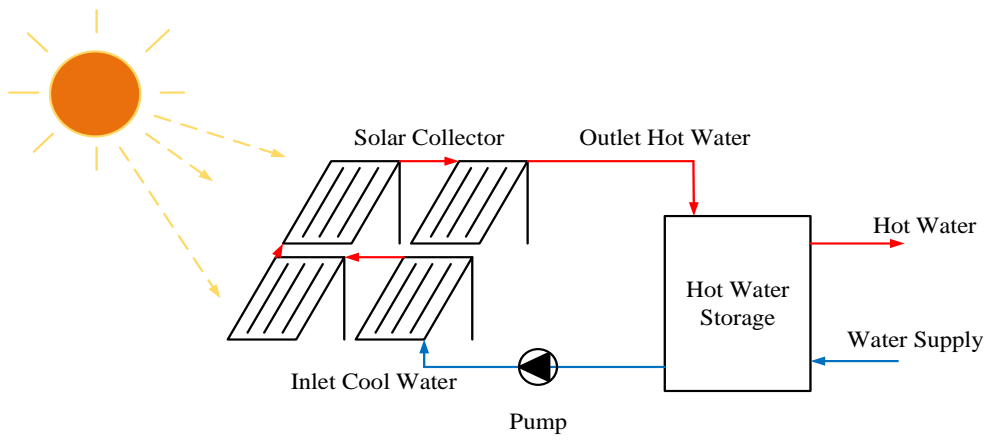

(a) diagram of solar water heating.

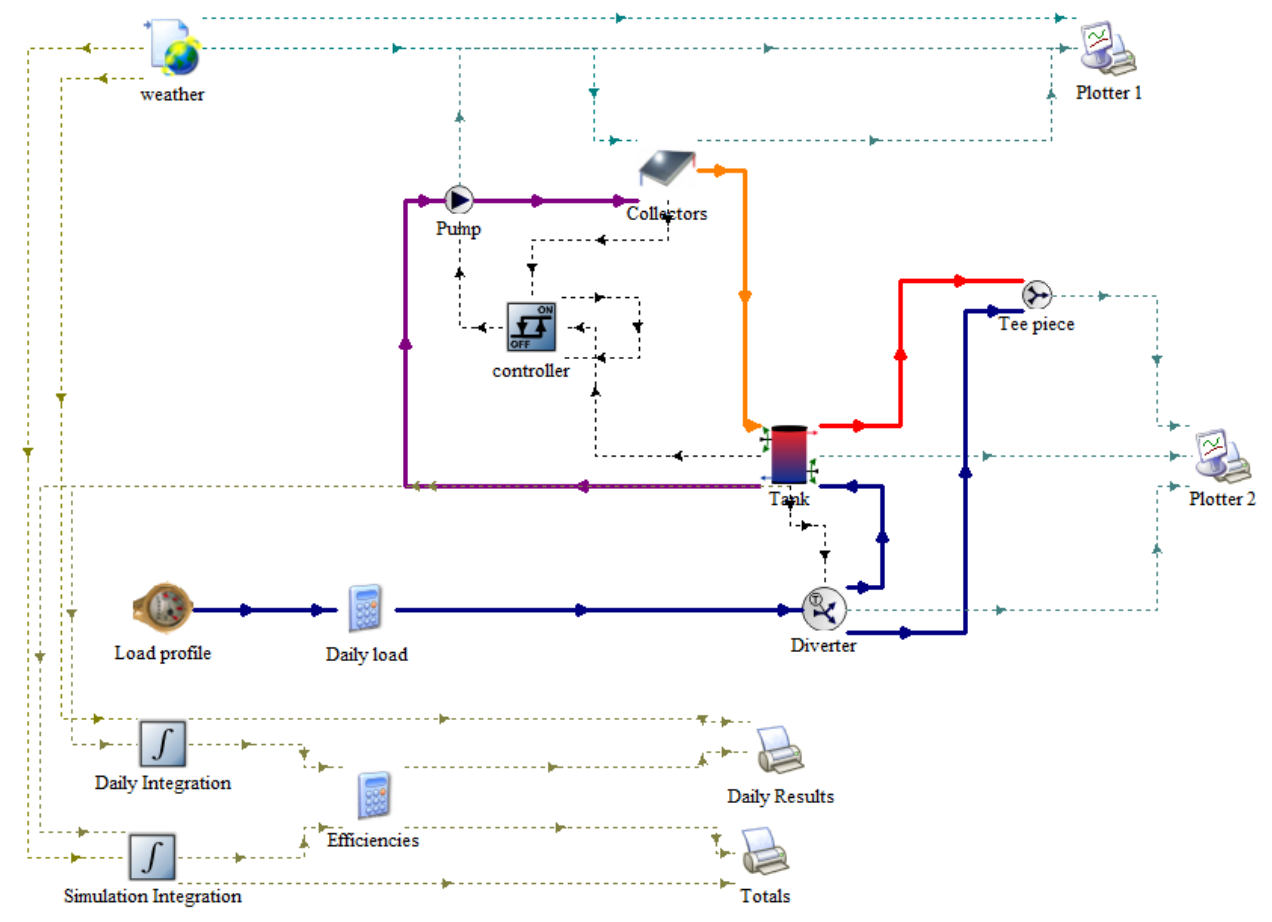

(b) diagram in RETscreen software.

Fig. 1. Diagram of solar water heating in residential building using in case study.

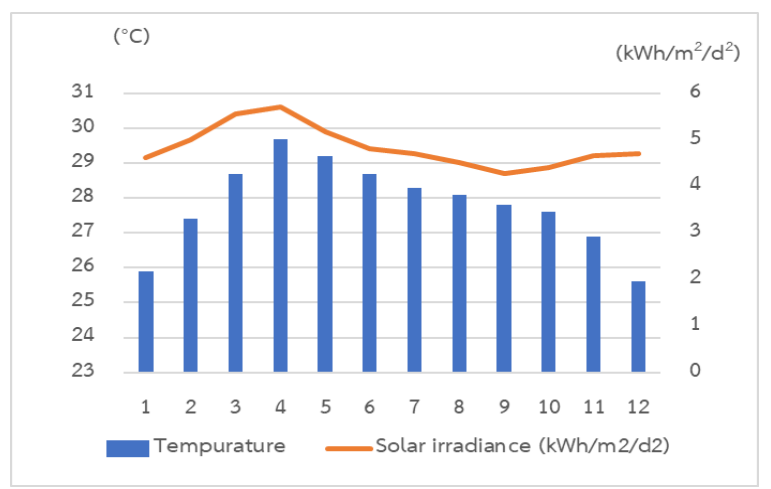

Fig. 2. Average temperature and solar irradiance in each month 
Table 5. Weather data in bangkok area

\begin{tabular}{lccccc}
\hline \multicolumn{1}{c}{ Month } & Temperature & $\begin{array}{c}\text { Relative Humidity } \\
(\%)\end{array}$ & Precipitation $(\mathrm{mm})$ & $\begin{array}{c}\text { Solar irradiance } \\
\left(\mathrm{kWh} / \mathrm{m}^{2} / \mathrm{d}\right)\end{array}$ & $\begin{array}{c}\text { Wind Speed } \\
(\mathrm{m} / \mathrm{s})\end{array}$ \\
\hline January & 25.9 & 68.1 & 11.03 & 4.62 & 1.3 \\
February & 27.4 & 71.4 & 18.03 & 5 & 2 \\
March & 28.7 & 71.8 & 42.21 & 5.56 & 2.5 \\
April & 29.7 & 71.5 & 102.11 & 5.7 & 2.3 \\
May & 29.2 & 74 & 265.69 & 5.18 & 1.9 \\
June & 28.7 & 74 & 257.5 & 4.81 & 1.9 \\
July & 28.3 & 74.1 & 272.85 & 4.7 & 1.8 \\
August & 28.1 & 75 & 292.23 & 4.52 & 1.8 \\
September & 27.8 & 78.8 & 375.66 & 4.27 & 1.3 \\
October & 27.6 & 77.8 & 260.83 & 4.41 & 1 \\
November & 26.9 & 69.5 & 57.85 & 4.66 & 1.2 \\
December & 25.6 & 64.2 & 16.12 & 4.7 & 1.2 \\
Annual & 27.8 & 72.5 & $1,972.12$ & 4.84 & 1.7 \\
Average & & & & \\
\hline
\end{tabular}

\section{Result}

The simulation has been done using RETscreen software in order to evaluate performance of solar water heating application on residential building in term of both energy performance and economic analysis using Bangkok, Thailand as case study location.

\subsection{Energy performance}

Department of Alternative Energy Development and Efficiency (DEDE), Ministry of Energy using ASHRAE 93-77 and EN 12975 standard to evaluate in the performance of solar collector in order to arrange the priority of supporting project. The standard evaluation can be done using equation (1)

$$
\eta_{c}=\frac{\int_{0}^{t} m C_{p}\left(T_{m}-T_{a}\right) d t}{\int_{0}^{t} I_{T i} d t}
$$

When

$\eta_{c} \quad=$ maximum efficiency of solar collector

$C_{p} \quad=$ specific heat of fluid exchanger $\left(\mathrm{J} / \mathrm{kg}^{\circ} \mathrm{K}\right)$

$m \quad$ = flow rate of fluid exchanger per area of solar collector $\left(\mathrm{kg} / \mathrm{m}^{2} \mathrm{~s}\right)$

$T_{m}-T_{a}=$ different temperature between inlet and outlet of fluid exchanger

The efficiency of the entire system can be calculate using equation (2)

$$
\text { Efficiency }=\eta-A *\left(T_{m}-T_{a}\right)-B *\left(T_{m}-T_{a}\right)^{2}
$$

When

$\eta \quad=$ maximum efficiency of solar collector

$C_{p} \quad=\left(\mathrm{J} / \mathrm{kg}^{\circ} \mathrm{K}\right)$

$m \quad$ = flow per area of solar collector $\left(\mathrm{kg} / \mathrm{m}^{2} \mathrm{~s}\right)$

$T_{m}-T_{a}=$ different temperature between inlet and outlet 
The resulted in term of energy performance of solar water heating is shown in Table 6 the system can generated delivered heating water it can be seen that hot water delivered from the system proportion to solar radiation. The summary of energy saving from proposed solar water heating system compare to currently used electrical water heating in term of power saving is shown in Table 7. The resulted indicated that solar water heating can reduced energy consumption by an average $2,155 \mathrm{kWh}$ annual or $87.4 \%$ compare to base case that used electricity to generating hot water.

Table 6. Solar water heating energy performance in each month

\begin{tabular}{lccc}
\hline Month & $\begin{array}{c}\text { Daily solar radiation }- \\
\text { horizontal } \\
(\mathrm{kWh} / \mathrm{m} 2 / \mathrm{d})\end{array}$ & $\begin{array}{c}\text { Daily solar radiation }- \text { tilted } \\
(\mathrm{kWh} / \mathrm{m} 2 / \mathrm{d})\end{array}$ & $\begin{array}{c}\text { Heating delivered } \\
(\mathrm{kWh})\end{array}$ \\
\hline January & 4.62 & 5.17 & 193.78 \\
February & 5 & 5.36 & 176.69 \\
March & 5.56 & 5.70 & 198.91 \\
April & 5.7 & 5.57 & 189.56 \\
May & 5.18 & 4.90 & 186.12 \\
June & 4.81 & 4.50 & 173.11 \\
July & 4.7 & 4.43 & 177.65 \\
August & 4.52 & 4.37 & 176.44 \\
September & 4.27 & 4.28 & 168.81 \\
October & 4.41 & 4.62 & 182.15 \\
November & 4.66 & 5.15 & 186.29 \\
December & 4.7 & 5.35 & 197.05 \\
Annual & 4.84 & 4.95 & $2,206.614$ \\
\hline
\end{tabular}

Table 7. Solar water heating system energy saving

\begin{tabular}{llll}
\hline & $\begin{array}{c}\text { Heating } \\
(\mathrm{kWh})\end{array}$ & \multicolumn{1}{c}{$\begin{array}{c}\text { Electricity } \\
(\mathrm{kWh})\end{array}$} & \multicolumn{1}{c}{$\begin{array}{c}\text { Total } \\
(\mathrm{kWh})\end{array}$} \\
\hline Base Case & 2,466 & 0 & 2,466 \\
Proposed Case & 259 & 51.7 & 311 \\
Fuel Saved & 2,207 & -51.7 & 2,155 \\
Fuel Saved $(\%)$ & 89.5 & 0 & 87.4 \\
\hline
\end{tabular}

\subsection{Economic analysis}

The index that will be used to measure the potential of investment are internal return rate (IRR) and discounted payback period due to its good to estimate the feasibility of the projected with data that include the inflation rate. The discounted payback period will be calculate using discounted cash inflow in equation (3) and (4) respectively

$$
\begin{gathered}
\text { Discounted Cash Inflow }=\frac{\text { Actual Cash Inflow }}{(1+i)^{n}} \\
\text { Discounted Payback Period }=A+\frac{B}{C}
\end{gathered}
$$

When

$i=$ Discounted rate

$n=$ Period of cash flow (years)

$A=$ Negative discounted cumulative cash flow

$B$ = Discounted cumulative cash flow at the end of the period A

$C=$ Discounted cash flow during the period after A

The IRR value can be calculated using equation (5). 


$$
I_{0}=\sum_{t=1}^{n} \frac{E S_{t}}{(1+I R R)^{t}}=0
$$

When

$I_{0}=$ Initial investment

$n=$ Project life (years)

$E S_{t}=$ Annual energy cost saving from year 1 to $\mathrm{n}$

$I R R=$ Internal rate of return

The result from economic analysis on simulate system shown that solar water heating can reduce energy cost 367 USD annual with assumption that electricity rate in Thailand is $3.91 \mathrm{THB} / \mathrm{kWh}$ or 0.119 USD/kWh (electricity cost per unit in November 2017). From the calculation, the IRR value is $2.8 \%$ using Thailand economic data that forecast inflation rate at $2 \%$. The proposed solar water heating can achieve discounted payback period at 15.6 years over the 20 years project life.

\section{Conclusion}

This paper proposed the feasibility analysis on application of solar water heating in residential building using Bangkok, Thailand as case study. The performance of proposed solar water heating has been evaluated in term of both energy and economic perspective. In term of energy performance, it can be seen that solar water heating can reduce energy consumption in residential building around $87.4 \%$ compare to currently used electrified water heating.

In term of economic analysis, it can be seen that solar water heating has with IRR at $2.8 \%$ and discounted payback period at 15.6 years. This economic analysis resulted shown the little potential in term of profit from investment due to scale of usage in residential building that significantly less than commercial building or industrial. However, the subsidy from government can reduce payback period and increase IRR value to the level that attract investor to installed solar water heating system in residential building

\section{Acknowledgements}

The authors wish to gratefully acknowledge financial support for this research from Srinakharinwirot University Research fund, Thailand.

\section{References}

[1] Energy Statistics. Energy Policy and Planning office, Ministry of Energy. (2018)

[2] Alternative Energy Development Plan (AEDP2015). Department of Alternative Energy Development and Efficiency, Ministry of Energy. (2015)

[3] Ge TS, Wang RZ, Xu ZY, Pan QW, Du S, Chen XM, Ma T, Wu XN, Sun XL, Chen JF, Solar heating and cooling: Present and future development, Renewable Energy, 2018; 126:1126-1140.

[4] Buker MS, Riffat SB, Building integrated solar thermal collectors - A review, Renewable and Sustainable Energy Reviews, November 2015; 51:327-346.

[5] Krauter S, Araújo RG, Schroer S, Hanitsch R, Salhi MJ, Triebel C, Lemoine R, Combined photovoltaic and solar thermal systems for facade integration and building insulation, Solar Energy, 1999; 67(4-6):239-248.

[6] Bornatico R, Pfeiffer M, Witzig A, Guzzella L, Optimal sizing of a solar thermal building installation using particle swarm optimization, Energy, May 2012; 41(1):31-37.

[7] Wu W, Dai S, Liu Z, Dou Y, Hua J, Li M, Wang X, Wang X, Experimental study on the performance of a novel solar water heating system with and without PCM, Solar Energy, 2018; 171:604-612.

[8] Lamnatou C, Chemisana D, Mateus R, Almeida MG, Silva SM, Review and perspectives on Life Cycle Analysis of solar technologies with emphasis on building-integrated solar thermal systems, Renewable Energy, March 2015, 75:833-846.

[9] Souliotis M, Panaras G, Fokaides PA, Papaefthimiou S, Kalogirou SA, Solar water heating for social housing: Energy analysis and Life Cycle Assessment, Energy and Buildings, 2018; 169:157-171. 
[10] Lamnatou C, Mondol JD, Chemisana D, Maurer C, Modelling and simulation of Building-Integrated solar thermal systems: Behaviour of the system, Renewable and Sustainable Energy Reviews, May 2015; 45:36-51

[11] Qu M, Yin H, Archer DH, A solar thermal cooling and heating system for a building: Experimental and model based performance analysis and design, Solar Energy, February 2010; 84(2):166-182.

[12] Dupeyrat P, Ménézo C, Fortuin S, Study of the thermal and electrical performances of PVT solar hot water system, Energy and Buildings, January 2014; 68(C):751-755.

[13] Nogueira CEC, Vidotto ML, Toniazzo F, Debastiani G, Software for designing solar water heating systems, Renewable and Sustainable Energy Reviews, 2016; 58:361-375.

[14] He Z. Solar water heating systems applied in high-rise residential buildings in china, Energy Procedia, 2016; 91:408-414.

[15] Rosiek S, Batlles FJ, Integration of the solar thermal energy in the construction: Analysis of the solar-assisted air-conditioning system installed in CIESOL building, Renewable Energy, June 2009; 34(6):1423-1431.

[16] Beccali M, Leone G, Caputo P, Ferrari S. Building integrated solar thermal design: assessment of performances of a low cost solar wall in a typical italian building. Energy Procedia, June 2016; 91:916-925. 